
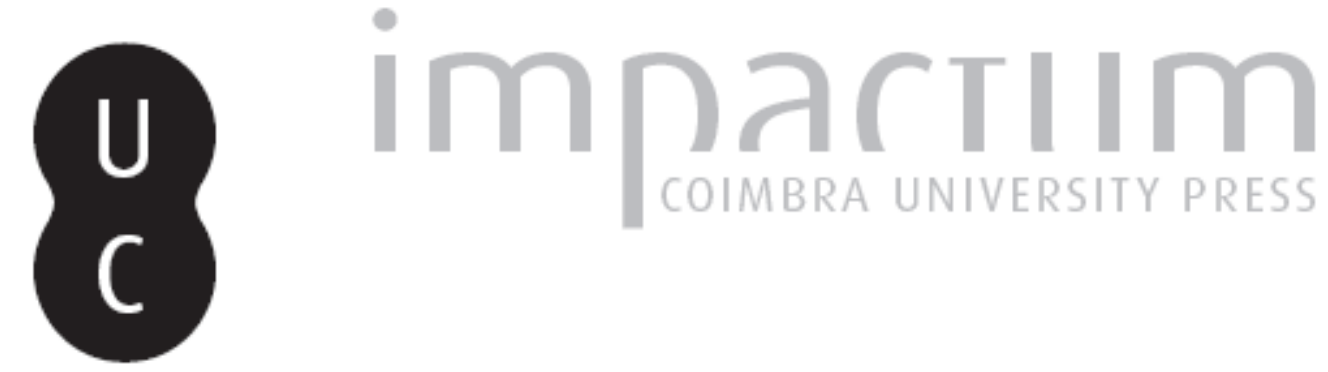

\title{
Parmenides psychologist: Part two: DK 6 and 7
}

Autor(es): $\quad$ Galgano, Nicola S.

Publicado por: Annablume Clássica; Imprensa da Universidade de Coimbra

URL persistente:

URI:http://hdl.handle.net/10316.2/41597

DOI:

DOI:https://doi.org/10.14195/1984-249X_20_2

Accessed : $\quad$ 26-Apr-2023 16:11:16

A navegação consulta e descarregamento dos títulos inseridos nas Bibliotecas Digitais UC Digitalis, UC Pombalina e UC Impactum, pressupõem a aceitação plena e sem reservas dos Termos e Condições de Uso destas Bibliotecas Digitais, disponíveis em https://digitalis.uc.pt/pt-pt/termos.

Conforme exposto nos referidos Termos e Condições de Uso, o descarregamento de títulos de acesso restrito requer uma licença válida de autorização devendo o utilizador aceder ao(s) documento(s) a partir de um endereço de IP da instituição detentora da supramencionada licença.

Ao utilizador é apenas permitido o descarregamento para uso pessoal, pelo que o emprego do(s) título(s) descarregado(s) para outro fim, designadamente comercial, carece de autorização do respetivo autor ou editor da obra.

Na medida em que todas as obras da UC Digitalis se encontram protegidas pelo Código do Direito de Autor e Direitos Conexos e demais legislação aplicável, toda a cópia, parcial ou total, deste documento, nos casos em que é legalmente admitida, deverá conter ou fazer-se acompanhar por este aviso.

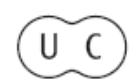




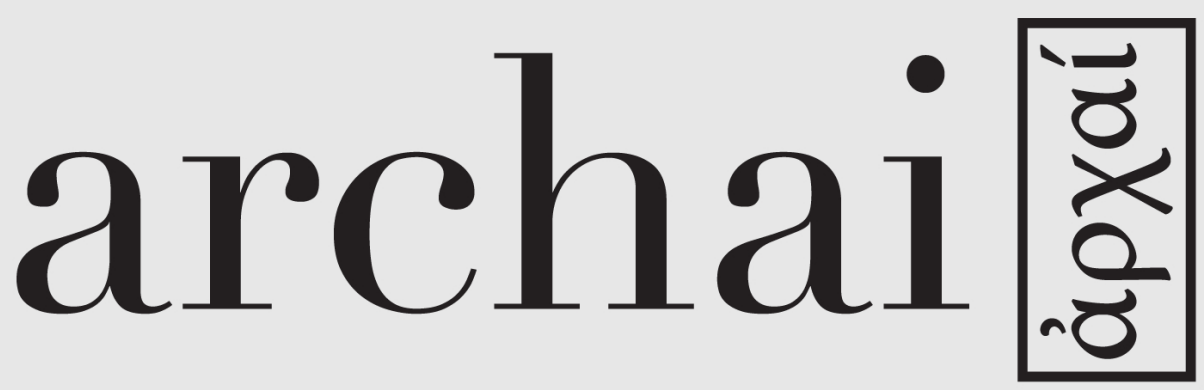

Revista sobre as origens do pensamento ocidental Journal on the Origins of Western Thought

20 | may-aug. 2017 


\section{Parmenides as Psychologist- PART Two: DK 6 AND 7}

archai圈

no 20 , may-aug. 2017

GALGANO, N. (2017). Parmenides psychologist - Part Two: DK 6 and 7. Archai, n. ${ }^{\circ 20}$, may-aug., p. 39-76

DOI: https://doi.org/10.14195/1984-249X_20_2

Abstract: The aim of this essay is to examine an aspect of Parmenides' poem which is often overlooked: the psychological grounds Parmenides uses to construct his view. While it is widely recognized by scholars that following Parmenides' view requires addressing mental activity, i.e. both the possibility of thinking the truth, as well as thinking along the wrong path that mortals follow, a closer examination of the psychological assumptions involved have, to my knowledge, not yet been attempted. I argue that by identifying and analyzing the psychological vocabulary in his poem, it is revealed that Parmenides was a keen observer of human mental behavior. Through these psychological (perhaps "cognitivist," following some recent categories) observations of thought processes, Parmenides gains insight into the structure of thought itself. The outcome of this inquiry reveals three notable conclusions: First, the poem contains a remarkably extensive use of strictly psychological vocabulary. Second, the presence of this psychological material and the lack of scholarly attention to it means there is a significant aspect of Parmenides intellectual 


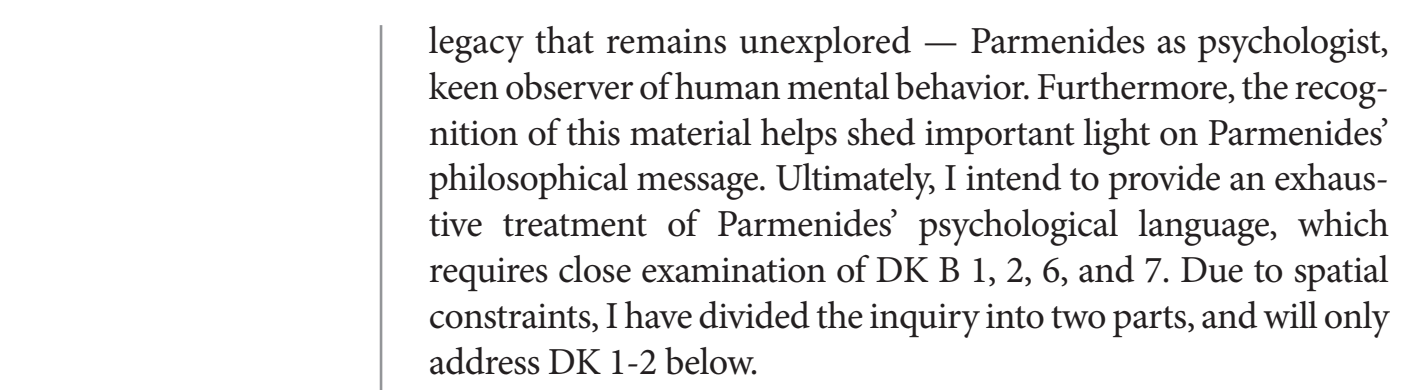

\section{archai圈}

no 20, may-aug. 2017

Keywords: Parmenides, Eleaticism, Presocratics, ancient epistemology, ancient psychology.

Galgano, N. (2017). "Parmenides psychologist - Part Two: DK 6 and 7." p. 39-76 


\section{FRAGMENT 6}

I continue my discussion of Parmenides' psychological observations with a close examination of Fragment 6 , as arranged by Diels-Kranz (DK) ${ }^{1}$ :

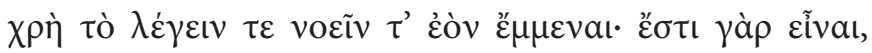

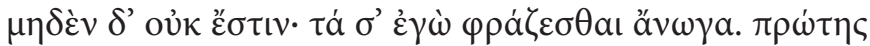

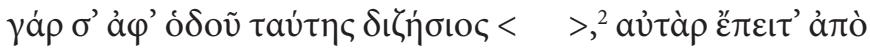

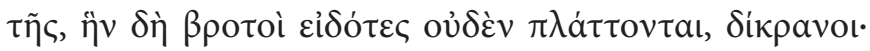

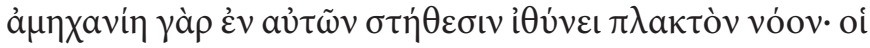

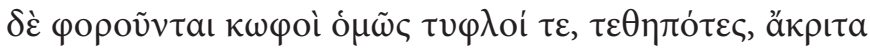

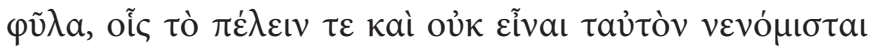

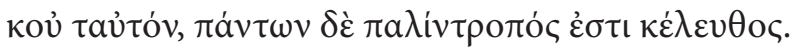

As with the entirety of Parmenides' enigmatic poem, there are numerous interpretative difficulties contained within this fragment, and various scholarly perspectives drawn from them. Most notable here is the question of whether DK 6.1-3 are referring to a possible "third way of inquiry," which would seem inconsistent with the exhaustive dichotomy introduced in DK 2. My own view is that the imputation of a "third way" is a mistake, one which has been definitively rejected by Cordero's arguments against the unfounded conjecture of Diels - great German philologist that he was - at the end of DK 6.3. ${ }^{3}$ Nevertheless, such philosophical details are not my concern in this inquiry, but rather the evidence for Parmenides psychological perspectives. In translating this fragment, I employ the same technical meaning ("cognitive operations) for the verb vocĩv and its cognates, as was established in my treatment of DK 2 in Part I of this inquiry.

\section{archai圈}

no 20, may-aug. 2017

Galgano, N. (2017). "Parmenides psychologist - Part Two: DK 6 and 7." p. 39-76 


\section{archai圈}

no 20, may-aug. 2017

Galgano, N. (2017). "Parmenides psychologist - Part Two: DK 6 and 7." p. 39-76
Mortals Follow the Wrong WAY: DK 6. 1-4:

It is necessary to say and to think that by being, it is, since it is possible to be, and nothing[ness] does not exist. This I order to proclaim since you <will begin $>$ with this first way of investigation, but then with that made by mortals who know nothing... ${ }^{4}$

In the first verse of DK 6 there is a need to say and to engage in a cognitive operation which recognizes that "by being, it is." This closely parallels the requirements set forth in DK 2, with additional content. DK 2.3 described the first way of inquiry as the path wherein cognitive operations lead to thinking that "it is" (whatever "it" refers to, and sense of "is" is employed), and that it is impossible to not be. While the path in DK 2.3 is explicitly correlated with "persuasion," the necessity for speaking and/or thinking that "by being, it is" is only added here in DK 6. Similarly, DK 2.5-7 outlines a second way of inquiry, wherein cognitive operations lead to thinking that "it is not" (again, whatever the referents and predications are), and that it is necessary not to be. This second way is described in DK 2 as a way which can neither be spoken of nor thought of. Note how this reverse-parallels the necessity to speak of and think that "it is," on account of the presence of Being in DK 6.1. That is, whereas it was impossible to

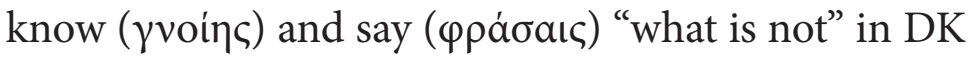
2 , here in DK 6 it is necessary to cognitively recognize

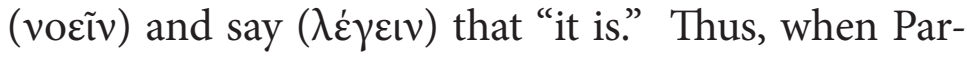
menides employs the phrasing 'since it is being ("

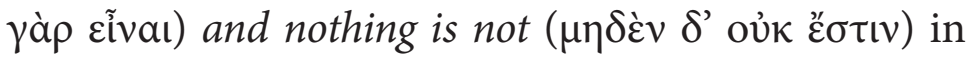
DK 6.1-2, he is referring back to and further clarifying the fundamental theses he first advanced in DK $2 .^{5}$ 
In addition to noting the parallels between DK 6 and DK 2, it is vital to keep in mind what Parmenides means by the word 'nothing' ( $\mu \eta \delta \dot{\varepsilon} v)$. As established in Part I, when Parmenides speaks about "what is not" ( $\tau$ ó $\mu$ ì ċòv), he does not mean to employ standard verbal operations (predicative, veritative or other) on some general subject. Rather, he is referring to the outcome of employing the process of negation to its logical extreme, a process which aims to reduce all things to "no thing," expressed by 'nothing' in English, and ' $\mu \eta \delta \dot{\varepsilon} v$ ' (literally, 'no one') in Greek. Thus, by "what is not," Parmenides refers to absolute nothing - which, as DK 2 makes clear, is such that it is impossible to be'.

If this inquiry sought to further explicate the philosophical meaning, these four verses would once again deserve far more extensive treatment. However, in keeping with the more restricted focus from Part I - strictly identifying and analyzing psychological content from the text - it is possible to move on at this point. In the remaining verses of DK 6, Parmenides continues on to explaining his method. Verses 3 and 4 are object of rough controversies, mainly for the lacuna in the original manuscripts. The goddess ask the kouros to 'do something' with the first path (we do not know what, for the lacuna), and also to 'do something' else with the path followed by mortals. This passage was and is object of a very great discussion in the fields of paleography, philology and philosophy; the topic at stake is is there is or there is not a third path pointed out by these words. However, we do not need indeed to face this discussion and we can jump it. To our ends, we will follow what Parmenides indicates as path (or

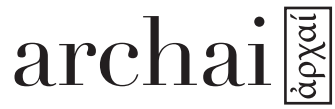

no 20, may-aug. 2017

Galgano, N. (2017). "Parmenides psychologist - Part Two: DK 6 and 7." p. 39-76 


\section{archai圈}

no 20, may-aug. 2017

Galgano, N. (2017). "Parmenides psychologist - Part Two: DK 6 and 7." p. 39-76 paths) and its characters and qualities, without any worry of find out if it is the first or second or third or more, because we are interested just in the psychological vocabulary.

\section{The Amazed Mortals: DK 6. 4B-9}

[...] the way upon which mortals, knowing nothing, imagine/forge two-headed, since a helplessness/lacking in their breasts drives the wandering intellect; and they are carried along, deaf and blind alike, amazed, people with no discernment, by whom being and not being are believed to be the same, and not the same. And this path is backwards-turning for all.

With this explicit discussion of mortal's mental behavior in verses 4-9, the most interesting aspects of Parmenides' psychological observations begin to surface. Parmenides says that mortals ( $\beta \rho \circ \tau o i)$ who know

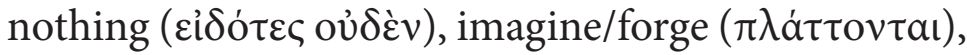
in a "two-headed" manner ('́kpavol). ${ }^{6}$ This is a result of some sort of lacking (ả $\mu \eta \chi \alpha v i \eta)$ in their mind (literally, in their breast, $\sigma \tau \eta \dot{\theta} \theta \sigma \iota v)$, a lacking that leads to a "wandering thinking," which is characterized as akin to being deaf, blind. In this state, it is as if they constitute their own race of people, one which is so utterly confused as to lack judgement entirely, such that they consider to be and not to be simultaneously both the same and not the same. Overall, this lacking results in their following a path which turns back on

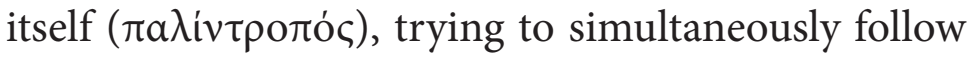
opposing - and thus contradictory - judgments. The meaning of this passage can be further explicated by paying close attention to the following terms: 


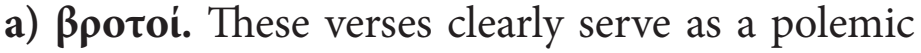
against certain objectionable cognitive behaviors of (at least some) mortals. Yet, who exactly are the "mortals" being referred to? There are numerous opinions on this amongst scholars. ${ }^{7}$ From my understanding, although the poem's intended audience is other men of learning, Parmenides here uses "mortals" to mean people who have a certain mind-set, without distinction between common people and 'wise men'. This is indicated by the qualifying description of mortals as 'knowing noth-

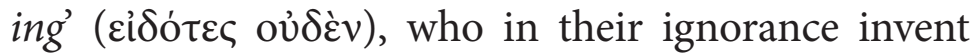

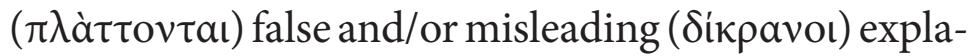
nations. This description - along with the other qualifications of "mortals" in this passage - are traditional descriptions found in the epic literature before Parmenides; the central contrast traditionally turns on the contraposition between divinity as powerful and omniscient, while mortals are limited and ignorant ${ }^{8}$. This contraposition is also commonly found in Ionic and scientific texts, which provide even closer parallels to Parmenides' usage. For example, in Xenophanes (one of Parmenides' masters), we find: “One God is greatest among gods and men, not at all like mortals in body or in thought." (DK 21 B 23, t. Lesher, 2001, p.96); "And of course the clear and certain truth no man has seen, nor will there be anyone who knows about the gods and what I say about all things. For even if, in the best case, one happened to speak just of what has been brought to pass, still he himself would not know. But opinion is allotted to all." (DK 21 B 34, t. Lesher, 2001, p.155). Similarly, in Alcmaeon: "concerning things unseen, (as) concerning things mortal, the gods have certainty, whereas to us as men conjecture (only is possible)" (DK 24 B 1, t. Freeman, 1948, p.40). Whereas the Archaic poets thought

\section{$\operatorname{archai}$ 詹}

no 20, may-aug. 2017

Galgano, N. (2017). "Parmenides psychologist - Part Two: DK 6 and 7." p. 39-76 


\section{archai 䀥}

no 20, may-aug. 2017

Galgano, N. (2017). "Parmenides psychologist - Part Two: DK 6 and 7.” p. 39-76 the races of gods and men were irreconcilably different in kind with respect to knowledge, by the $5^{\text {th }}-4$ th centuries BCE, a more nuanced comparison arises: while divine knowledge is perfect, human knowledge (not mere opinion), while imperfect, is possible. Whereas the Olympic religion maintained a strict separation between human and divine attributes, the later Mystery religions offered a ritualistic means by which to bridge this separation. Similarly, the new Ionic (and later Italic) naturalism constructed a new intellectual paradigm, whereby new methods for understanding the world were developed, gradually elevating human capacities for problem-solving, and thereby encroaching upon traditionally divine purviews. This improvement in the lot of mortals is not based upon men becoming gods, but because men can partially overcome the amēkhaniē of human condition through their newfound knowledge. However, this development is once again gradual. Xenophanes and Alcmaeon had not yet found a reliable method, so they treat human knowledge as something conjectural, a possibility that might be realized through further study that follows a proper method. Parmenides, on the other hand, believes himself to be in possession of just such a method, and this tool finally permits him to speak in terms of following a path that leads to "true conviction" ( $\pi i \sigma \tau \iota \varsigma \grave{\alpha} \lambda \eta \theta \eta \dot{\varphi} \varsigma$ ) in Parmenides. In order to indicate this gradual development towards genuine knowledge, Parmenides begins by contrasting it with the more limited human condition found in the epic tradition, using the epic term brotoi ("mortals") as a short-hand placeholder indicating that traditionally limited condition".

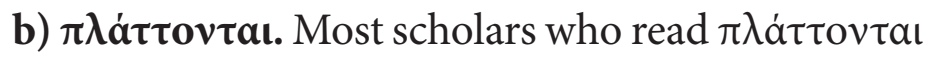
understand it to mean 'err'; however, this results in the 
psychological content of the Parmenidean expression being completely lost. By adopting a more literal translation - i.e. 'invent' or 'forge' - it is possible to preserve this content, and provide a more coherent point. On this reading, the problematic mental activity is that ßpotoì--again, in the traditional sense, whose ordinary

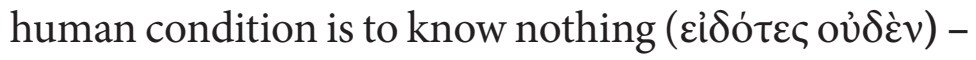
invent their own erroneous paths ( $\pi \lambda \dot{\alpha} \tau \tau o v \tau \alpha$ ) , rather than following the correct path of inquiry ${ }^{10}$. It is fitting and natural that such mortals would naively forge/invent subjective explanations, as they lack any reliable methodology by which to overcome their ordinary condition and explain the world objectively. Without a reliable objective method, they resort to creation of (more or less internally consistent) explanations that make intuitive sense, driving the creation of traditional myths. Cordero (1984, p.148) makes this point clear, pointing to the use of $\pi \lambda \dot{\alpha} \sigma \sigma \omega$ in Plato's Timaeus, where Critias says: "not invented myth but true ac-

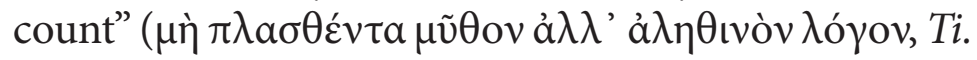
26.e.4). As noted in Part 1, the awareness that mythical explanations are mere fantasy is already present in the masters of Parmenides, and the overarching subject of Parmenides' poem is not the affirmation of 'being' (as a certain type of idealistic historiography prefers), but the distinction between true and untrue forms of persuasion - respectively parallel to true accounts v. mere fantasy - as made clear in the programmatic outline in DK 1. 29-30. As the gods (with only some notable exceptions) speak the truth, the lack of true persuasion would customarily find its origin in mortals - i.e. the invention of 'false' myths is a craft of mortals. Hence, to impute the invention of false myths to mortals here is perfectly consistent with his proposal. Moreover, the general criticism of mythical modes of thought, while

\section{archai圈}

no 20, may-aug. 2017

Galgano, N. (2017). "Parmenides psychologist - Part Two: DK 6 and 7." p. 39-76 


\section{archai 䀥}

no 20, may-aug. 2017

Galgano, N. (2017). "Parmenides psychologist - Part Two: DK 6 and 7.” p. 39-76 admittedly more readily explicit in Xenophanes, is not overly hidden in the suggestive verses of the Parmenides' poem, as will become clear below, in the discussion of fr. 7. To recount, here it should be emphasized that Parmenides observes a common mental behavior: mortals, knowing nothing, fantasize and invent explanations, attempting to account for some phenomena of the world. In doing so, Parmenides is not so different from modern psychologists, who in their attempts to account for that which they do not have any genuine capacities for understanding, offer more or less plausible invented explanations. Nevertheless, while Parmenides casts this common psychological behavior in terms of traditional conceptions regarding mortal limitations, and in doing so treats it as a failing, it is vital to note that he does not hold this condition to be a fatally permanent lacking that cannot be overcome, nor a moralistic rebuke. Furthermore, it is not a failing that applies to certain persons, under certain conditions. Rather, Parmenides is like the modern psychologist scientist - one who in this case identifies a universal problem for human beings in a neutral manner (withholding judgment), who then seeks to prescribe

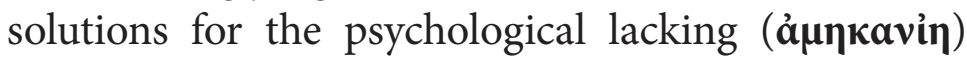

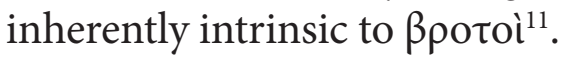

c) à $\mu \eta \chi \alpha$ vin. This term is a common epithet describing the inferior condition of mortals in the epic and lyric traditions. While many scholars adopt and translate its more literal meaning 'lack of resources' ${ }^{12}$, others prefer to translate 'perplexity'13, emphasizing the cognitive context. In any case, the "lacking" here must clearly refer to some human limitation, one that tends to result in mortals developing a wandering behavior of noos (iӨv́veı $\pi \lambda \alpha \kappa \tau$ òv vóov). 
The preponderance of scholars focus on contrasting this overall negative characterization of mental behavior for ordinary $\beta \rho o \tau o$ with Parmenides' description

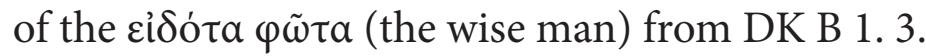

However, I think there is a deeper psychological

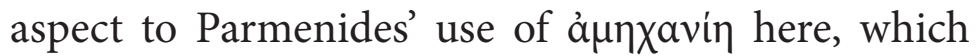
has gone so far unnoticed. Recall that Parmenides says that the lack of resources (a $\left.\mu_{\mu \eta} \chi \alpha v i \eta\right)$ in their

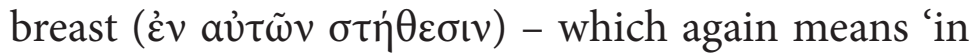
their mind' here (as ètor, in 1.29) - causes a wandering thinking. This means that Parmenides is not referring to a generic lack of resources, nor to that ge-

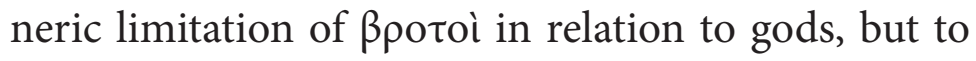

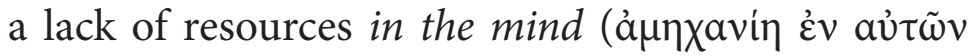
$\sigma \tau \eta \dot{\eta} \theta \sigma \mathrm{v})$. The precise wording of the goddess make this limited scope clear: "because ( $\gamma \grave{\alpha} \rho)$ inability of

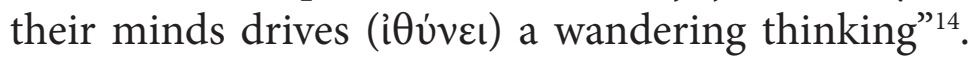
In other words, it is not about the incapacity of mortals as a whole, but just a part, i.e. human mind. The conception of à $\mu \eta \chi \alpha v i \eta$ ("lack of resources"), as an alpha-privative $(\dot{a}+\mu \eta \chi \alpha$ vin $)$, implicitly invokes its oppositional root $\mu \eta \chi \alpha v \eta$ ' ("possession of resources').

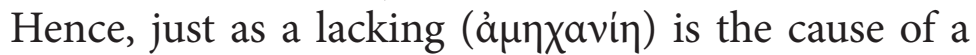
wandering mental behavior for mortals - wherein they first affirm something and after, affirming the opposite, contradict themselves - it would seem that were those same mortals to possess a proper mental "resource" or "tool" ( $\mu \eta \chi \alpha v \eta)$, they could thereby avoid this error. Thus, Parmenides may instead by drawing a more general and universal contrast between the explicitly noted psychological lacking (å $\mu \eta \chi \alpha v i \eta)$, and its most direct opposite - a "possession of resources," or a "tool" ( $\mu \eta \chi \alpha v \eta)$ for the mind, by which this unfortunate condition might be overcome. And it is precisely

\section{archai莀}

no 20, may-aug. 2017

Galgano, N. (2017). "Parmenides psychologist - Part Two: DK 6 and 7." p. 39-76 


\section{archai 䀥}

no 20, may-aug. 2017

Galgano, N. (2017). "Parmenides psychologist - Part Two: DK 6 and 7.” p. 39-76

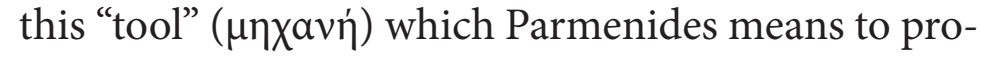
vide, allowing mortals to finally overcome their traditionally limited condition with respect to inquiry, and discovering accounts that are truly persuasive. Thus, Parmenides has once again taken a common lyric and

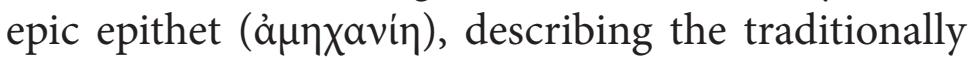
inferior condition of mortals, and used it in a more specialized way to indicate a flawed nature that can be overcome. Here, he is indicating a particular psychological behavior which leads mortal thinking astray, for which his own endorsed way of thinking can provide a corrective solution. This becomes more evident as the final verses are considered more closely.

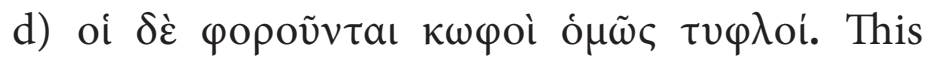
phrase serves to further describe the effects of a mortal mind that suffers from amēkhaniē, and special attention must be paid to the term omōs, 'alike' ${ }^{15}$. The grammatical subject oi refers back to broto $i$, and the verb phorountai (here a passive of phoreō) points back to the amékhanie of the mind that drives the brotoi, and hence as the cause by which they are driven. Mortals (brotoi) are here described as "driven alike deaf and

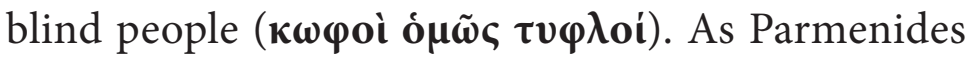
is clearly attempting to offer novel descriptions of mental activities - sensations, dynamics, and concrete mental deeds - he should be not be taken to be referring to sense perception in general, nor that such mortals are literally deaf and blind. Rather, he once again seems to be struggling to adequately express himself with the extant vocabulary available to him. That there is a tendency to link sensitiveness in and clarity of sense perception with correct reasoning is even preserved in modern language, as is evident with words like 'evidence', 'clearness', etc. 
Given these considerations, it seems best then to take him to be pointing to some likeness between blindness/deafness and the psychological á $\mu \eta \chi \alpha v i \eta$ under discussion - that there is some way in which the lacking in their mind makes mortals mentally deficient in a way similar to how people with a lack of ability in their sense-organs are deficient in their sensory perceptions ${ }^{16}$.

Now, how exactly might a mind without resources drive people in a way resembling deafness and blindness? Such a mind relies upon wandering cognitive operations (plankton noon), lacking the proper tools (amēkhaniē) by which they might correctly understand the world. So, lacking the mental means by which correct understanding is achieved, they fail to understand properly. Similarly, those who are deaf and blind might be understood as sharing: a) a lacking in the sensory tools (i.e. sense organs) by which proper sense perception is achieved, and thus their minds fail to obtain the data needed for certain sense-perceptions, or b) a particular lacking in the mind itself, which prevents them from understanding the data which their organs collect, and thus fail to generate certain sense-perceptions in their mind. In either case, their sense-perception of reality would fail due to a lacking in capacity, just as those who lack the sufficient tools for inquiry fail to grasp reality objectively and truly. Whatever the proper analogy, Parmenides has rightly ascertained that there is a distinct role for the mind in properly understanding reality, and the outcome of the mental functions depends upon correct and incorrect (trustworthy and untrustworthy) methods/tools for obtaining such understanding.

\section{archai或}

no 20, may-aug. 2017

Galgano, N. (2017) "Parmenides psychologist - Part Two: DK 6 and 7." p. 39-76 


\section{archai圈}

no 20, may-aug. 2017

Galgano, N. (2017). "Parmenides psychologist - Part Two: DK 6 and 7.” p. 39-76

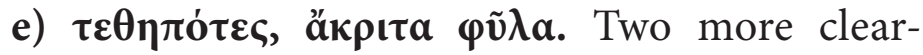
ly psychological notions are found in this clause.

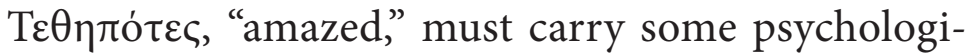
cal meaning with respect to "mental sharpness." In context, this "amazement" is another result of mortals' ả $\chi_{\chi} \alpha$ vin, serving a similar novel descriptive function as "deafness and blindness," with respect to their mental incapacity, Ruggiu (1975, p.143) offers an instructive to comparison of the Parmenidean usage here with a passage from Homer (Od. 23. 105), noting that a 'great surprise' results in Penelope's incapacity to speak or see: "the heart in my breast is lost in wonder, and I have no power to speak at all, nor to ask a question, nor to look him in the face." (Murray, 1919 ${ }^{17}$. Thus, it would seem that there was already a recognition that being "amazed" ( $\tau \dot{\varepsilon} \theta \eta \pi \alpha)$ is closely associated with inabilities (i.e. á $\mu \eta \chi \alpha v i$ ) in: speech, inquiry, and sight. However, this attribute ( $\tau \dot{\varepsilon} \theta \eta \pi \alpha)$ goes further here, making such brotoi a specific hu-

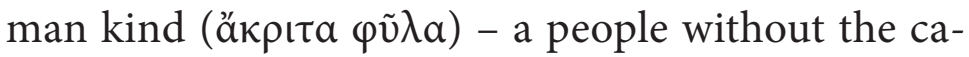
pacity for exercising judgement (крíбı). The judgment that broto $i$ lack is the ability to properly draw a distinction between being and non-being, which they take to be both the same and not the same (oĩ

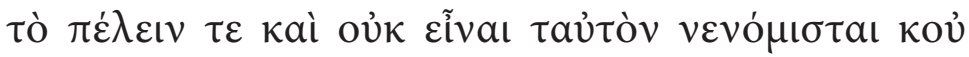

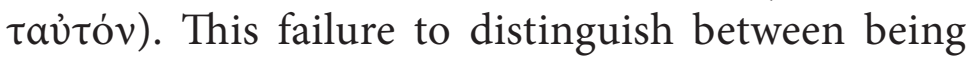
and not being is once again a failure in cognitive operations, a mental activity that confounds brotoi on

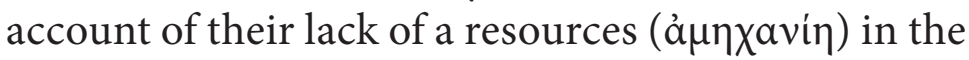
mind. Were mortals to possess the appropriate mental tool ( $\mu \eta \chi \propto$ avin) which makes such distinctions possible, they could overcome this limitation. Without this resource, cognitive operations have no clear direction, which is why Parmenides goes on describe the path of mortals as... 


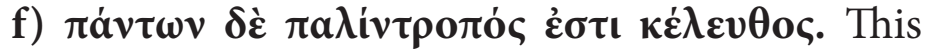
much-discussed statement on the "reversibility" ( $\pi \alpha \lambda i v \tau \rho \circ \pi$ ó $)$ of the path brotoi follow ends this fragment ${ }^{18}$. However, in light of the difficulty brotoi face in distinguishing between being and not being, and their simultaneous, contradictory judgments concerning each, it seems more apt to translate $\pi \alpha \lambda i v \tau \rho o \pi$ ó more literally, describing their path as "contrary"19. So this fragment ends, trading heavily on psychological observations, with a closing description of mental behavior as an erroneous "path of inquiry" - upon which affirmation and negation are thought to be both the same and not the same, on account of a lack of discernment and mental capacity (or tools) in the minds of mortals.

\section{Conclusion of FRAgment 6}

Verses 4-9 of Fragment 6 contain a focused description of mortals' mental behavior, which suffers from an initial problem. This problem is the lacking of a certain mental resource/tool, the result of which is that mortals suffer in their mental capacity in some way similar to how the deaf and blind suffer in their perceptual abilities. Being so intellectually "amazed" ( $\tau \varepsilon \theta \eta \pi$ ó $\tau \varsigma)$, they are a race unto themselves, inca-

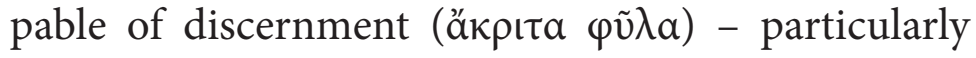
in the case of distinguishing being versus not being. In short, the lack of a proper method of inquiry leads them invent erroneous paths ( $\pi \lambda \dot{\alpha} \tau \tau o v \tau \alpha)$ for inquiry, so that when they attempt to explain the world, their confusion leads them to simultaneously contradict themselves, along with one another. Most scholars emphasize the negative warning in this passage - that there is a path that mortals erroneously follow

\section{archai圈}

no 20, may-aug. 2017

Galgano, N. (2017). "Parmenides psychologist - Part Two: DK 6 and 7." p. 39-76 


\section{archai 䀥}

no 20, may-aug. 2017
Galgano, N. (2017). "Parmenides psychologist - Part Two: DK 6 and 7.” p. 39-76 in their confusion, which a "knowing man" should not, as this path is not in accord with the path of being, wherein the still heart of truth lies (treatment of which seems to immediately follow, in Fragment 8, on Diels-Kranz's arrangement). However, while I do think that Parmenides is describing mortals' limits, his criticism is more narrowly focused than is often realized. Parmenides is not here comparing limited mortal capacities for understanding with the powers of divinity; rather, he is identifying a failure in psychological activity (the á $\mu \eta \chi a v i \eta)$ with respect to argument formation and proper inquiry. Recognizing this psychological lacking (it would be inappropriate to say dysfunction), Parmenides proceeds to offer a psychological diagnosis for mortal misunderstandings - that mortals lack the proper tool(s) for following the path of true persuasion. In contrast, the goddess clearly possesses this tool, as she does not suffer from such a psychological lacking. Thus Parmenides, via the poem's spokes-goddess, sets out a didactic program for the youth, by which the goddess will instruct her disciple by providing a ( $\mu \eta \chi \boldsymbol{\alpha} \boldsymbol{v} \eta \dot{)})$ - in this case, an artificial tool (as revealed below) by which the lacking in mortal psychology can be overcome. So, while mortals do suffer from a lacking (amékhaniē,) Parmenides' lesson is that there exists a certain tool by which this flaw in mental operations can be overcome, removing them from their condition as

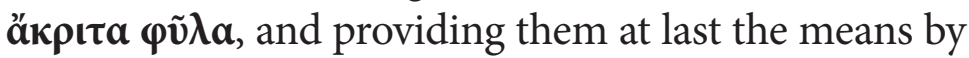
which they can properly distinguish true persuasion from its absence, and being from not being.

\section{FRAGMENT 7}

Fragment 7 is an amalgamation, generated from apparently overlapping verses from several sources: 
Plato, Sextus Empiricus, Simplicius and Diogenes Laertius. However, I once again leave the more exegetical considerations aside, maintaining a focus on the psychological vocabulary - the consideration of which arrangement of the quotations and fragments have relatively little impact. Here is the text, according to Diels ${ }^{20}$ :

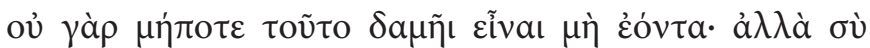

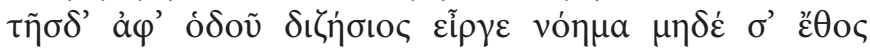

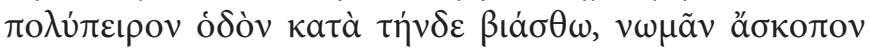

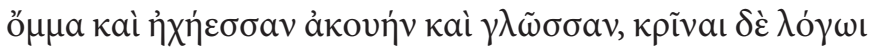

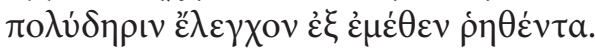

The immense philosophical value in the first two lines is undeniable. Here, we find an initial formulation of the Principle of Non-Contradiction, a conception which Aristotle will famously clarify further in his own version. Also, worthy of note is the repetition of the basic Parmenidean concern - i.e. to discover and distinguish the different paths of inquiry for cognitive operations, and upon analysis make use of the proper path. Here he seems to conclude this investigation into the paths that are possible, picking

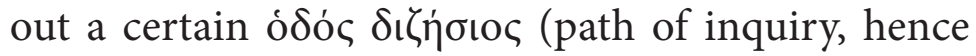
cognitive mental processes) which from this point forwards the kouros should make sure to avoid - i.e. keeping his inquiring thought (i.e. cognitive opera-

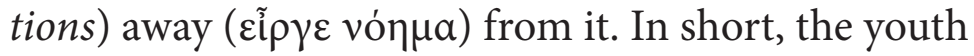
is commanded not to follow this process of thinking because it is contradictory. However, there is little of psychological relevance in these first two verses. For the purposes of this inquiry, it is important to look more closely at what follows

\section{archai嚎}

no 20, may-aug. 2017

Galgano, N. (2017). "Parmenides psychologist - Part Two: DK 6 and 7." p. 39-76 


\section{archai圈}

no 20, may-aug. 2017

Galgano, N. (2017). "Parmenides psychologist - Part Two: DK 6 and 7.” p. 39-76
On the other hand, verses 7.3-6 require special attention, as there are multiple meanings embedded within them. These verses clearly provide an exhortation to avoid the path that confuses being and not being. There are two general groups which previous scholarly positions on this fragment can be sorted into. The first group overlooks the fact that Parmenides'

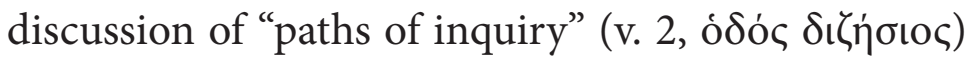
picks out a type of mental behavior, and here takes Parmenides to be speaking against the trustworthiness of the senses ${ }^{21}$. In contrast, the other group does recognize that "paths of inquiry" is about mental behavior - that is, about methods of inquiry ${ }^{22}$. My own reading, of course, tends to fall into the latter position, with respect to this controversy. However, my view is also largely different from that of other scholars in many ways, particularly with respect to the meaning of the last verse (fr. 7.6), as will be made clear below.

Overall, I take the general meaning of this fragment as an exhortation to avoid the path that leads to thinking that being and non-being are the same and not the same. More specifically in this context, the fragment warns against unreflectively following cultural norms regarding mental behavior and senseperception. For the goddess conjoins her injunction against following the path which confuses being and not being, by demanding the youth also avoid letting the habit that was experienced many times force you on that path. This cultural inheritance of habits - in which eyes, ears and tongue are mixed up - results in bad judgement and misunderstanding, unlike proper and persuasive discourse. 
The overarching argument seems to go as follows. Here, the goddess again references paths of cognitive operations. These are paths along which thoughts can be properly sequenced into a coherent argument. The identity of these paths relies upon psychological distinctions made earlier in the poem. First, that there are good and bad arguments (those of true persuasion, and those without true persuasion, fr. 1.29-30). Second, that good arguments (wherein persuasion accompanies the truth, fr. 2. 4) are ultimately the result of a special resource of mind - the lack of which capacity in mortals results only in the production of bad arguments, for they erroneously believe being and non-being are both the same and not the same. Here, in 7.1-2, the goddess adds to this, claiming that being and non-being are in fact distinct, since non-beings never become being. As following that path results in contradiction, the youth must avoid it entirely, and not allow the repeated habit to force him upon it.

\section{Cultural habits, the verse $7 \cdot 3$}

The goddess orders the kouros to stay away from that path and, at the same time, warns against being forced upon it by "much-experienced habit" (relating to eyes, ears, tongue and discourses). What is this "habit"? It is a habitual behavior of mind or, in Parmenides' words, a habitual way of thinking. The word $\pi$ o $\lambda \dot{u} \pi \varepsilon\llcorner\rho o v$ literally means 'experienced many times ${ }^{23}$. Parmenides is thus picking out the experience of thinking along certain a certain way ("path"), which having been repeated many times, has become habitual - i.e. an "automatism" of the mind. Parmenides here seems to be observing that there are tendencies in mental behavior, oft referred to as forma

\section{archai圈}

no 20, may-aug. 2017

Galgano, N. (2017). "Parmenides psychologist - Part Two: DK 6 and 7." p. 39-76 


\section{archai圈}

no 20, may-aug. 2017

Galgano, N. (2017). "Parmenides psychologist - Part Two: DK 6 and 7.” p. 39-76 mentis. Such mental behavior is learned, through repetition, until it becomes automatic (habitual). The mental habituation Parmenides is criticizing here is one that depends upon acculturation - a forma mentis of a group ( $\varphi \tilde{v} \lambda \alpha$, fr. 6.7). The fact that very different ways of thinking can be the result of culture was already recognized in Parmenides' time. Xenophanes makes this clear in his famous commentary about the variety of views held by the gods in different cultures (fr. DK B 14 and 16). Thus, it is no surprise to find his disciple, Parmenides, thinking along similar lines. Parmenides goes further than his master, however. Whereas Xenophanes points to and describes what the differences are across cultures, Parmenides offers explanations for how these differences are generated and reproduce one another. Parmenides recognizes that certain ways of thinking inform cultural norms, and cultural norms drive us towards certain ways of thinking. In other words, not only does Parmenides posit that different ways of thinking lead to cultural differences, but that cultural differences themselves lie in the background to and inform certain ways of thinking, resulting in certain general patterns for learning and thinking (i.e. not just with respect to religious views). Just as immersion in a culture generates certain manners of thinking, so can certain ways of thinking reproduce cultural norms, further reinforcing that culture and it norms, which in turn again reproduces the culturally-based ways of thinking, and so on, mutually reinforcing one another. Therefore, in the process of explaining how the learning process works, and criticizing certain culturally-grounded mental habits, Parmenides is also offering severe criticism 
against traditional ways of thinking - particularly those which reproduce themselves through unreflective repetition, forcing thought (cognitive operations) to remain on its original route (i.e. that of the traditional culture). Furthermore, alongside this cultural criticism of tradition in general, Parmenides is also criticizing a specific, sensory-based method of inquiry, as well as educational norms.

Many scholars have thought that these criticisms are directed towards some specific philosophical school(s) or thinker(s). However, the possible philosophical targets were all quite recent, relatively close to Parmenides' own time. Furthermore, none of these ways of thinking are representative of traditional culture. These factors make it quite difficult to square Parmenides' description of his target as thought which is

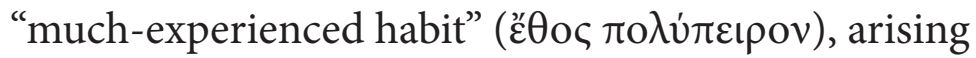
from a cultural context. As there is no philosophical target explicitly picked out in the text, despite the fact that this criticism is advanced by a divine mouth-piece, it would seem Parmenides' target must be mythic (i.e. religious) thought. Mythic thought is the problematic cultural tradition which erroneously constrains thinking (cognitive operations) onto wandering paths

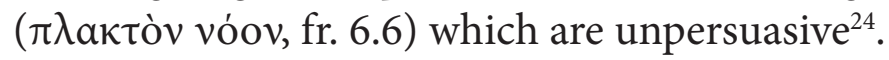

\section{Sight, HeARING AND TONgUe: Verses 4 AND 5}

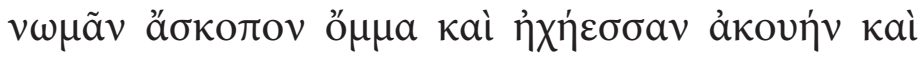
$\gamma \lambda \tilde{\omega} \sigma \sigma \alpha v$ : Once again, Parmenides here uses periphrases to explain his point of view. The goddess has already enjoined the youth to not habitually follow the "much-experienced path," which involves habitually

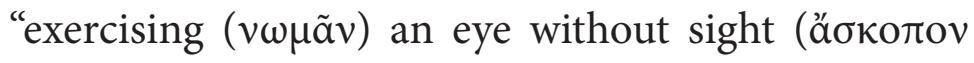

\section{archai萇}

no 20, may-aug. 2017

Galgano, N. (2017) "Parmenides psychologist - Part Two: DK 6 and 7." p. 39-76 


\section{archai 䀥}

no 20, may-aug. 2017
Galgano, N. (2017). "Parmenides psychologist - Part Two: DK 6 and 7.” p. 39-76

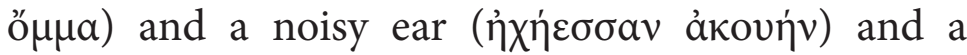
tongue $(\gamma \lambda \tilde{\omega} \sigma \sigma \alpha \nu)^{25}$. If this is limited to an epistemological reading - as most scholars do - there seems to only be a straightforward metaphor for confused and imprecise cognition, reliant upon sense-perception alone. However, as the Parmenidean sensitiveness to psychological observation has been established above, the introduction of an epistemological metaphor is less likely in this context. As outlined in the treatment of Fragment 6, imagery of confused senses are commonly used in an attempt to imperfectly capture how a lacking in mental capacity and/or resources leads to similar mental confusions. Parmenides seems to similarly rely upon this analogous imagery here. An eye that does not see is an eye that provides data to the mind, but the mind lacks the appropriate mental capacities (cognitive operations) to incorporate the images from the physical eyes into a coherent sense perception. Similar treatments could of course be provided regarding deafness. Also, it is worth considering how discourse, even that which is free of contradictions and compelling, are incapable of persuading one who has a 'ringing' (confused) ear. In any case, the meaning here should not be understood as a metaphorical rejection of the inadequacy of sense-perception in relation to reason. Rather, it is an attempt at description of a mental behavior and, in this special case a description of cognitive operations, which uses commonly understood language of sensory deficiencies to indicate failures of mental operations.

JUdGING BY THE LOgOS, VERSES 5 AND 6.

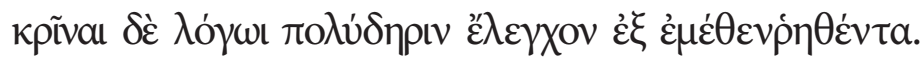
Most scholars translate this clause in approximately 
the following way: "judge by reason the too much contested argument which has been given by $\mathrm{me}^{\text {"26. }}$. From Plotinus to the mid- $20^{\text {th }}$ century, this has been considered one of the high points of the poem. However, there are many historical problems faced by putting so

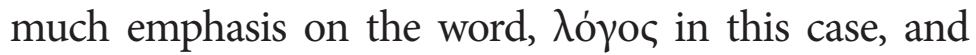
translating it as "reason." While this same word will certainly come to have an incomparably important role in history of philosophy with this meaning ("reason" and "rationality"), it does not seem to have held this platonistic sense in Parmenides' time, as the past fiftyplus years of scholarship have shown. However, restoring the poem to avoid this interpretative element has progressed slowly. To better capture the sense of these verses without imputing the anarchistic "reason," I here employ the philological interpretation and translation of Christopher Kurfess (2012, p.76-77), who offers a reading which I believe to be far more in keeping with Presocratic and Parmenidean perspectives:

But do you bar thought from this way of seeking, And let not habit of much experience force you, along this way, To ply an aimless eye and echoing hearing And tongue, and to judge, by means of speech, the elenchos Spoken by me (to be) much-contending.

This translation "and let not habit of much experience force you [...] to judge, by means of speech, the elenchus ${ }^{27}$ spoken by me (to be) much-contending" seems to me much more natural, and more adherent to not only to the spirit and mentality of those early thinkers, but also to the spirit of the text itself. Though Kurfess considers the Parmenidean warning in these lines 'curious', I think that the goddess here presents

\section{archai圈}

no 20, may-aug. 2017

Galgano, N. (2017). "Parmenides psychologist - Part Two: DK 6 and 7." p. 39-76 


\section{archai圈}

no 20, may-aug. 2017

Galgano, N. (2017). "Parmenides psychologist - Part Two: DK 6 and 7." p. 39-76 a powerful argument against seductive rhetoric in discourse. This criticism applies not only to political rhetoric (Parmenides himself was a successful politician of an eunomic polis $\left.{ }^{28}\right)$, but also to mythical rhetoric and discourse that is concerned with describing the structure and functions of the world. Seductive rhetoric is characterized by the traditions of using rhythmic speech and formulaic models, inviting the listener to 'see' the world from a particular perspective (weltanschauung). The old, traditional weltanschauungen was grounded in mythical thinking, a world-view the new cultural perspectives developed by the Presocratics - particularly the more theoretical ones - often challenge, directly or indirectly. As noted above, cultural perspectives tend to reinforce and reproduce themselves, and in doing so, reject new alternatives. This is why here the goddess implores the youth to avoid such prejudiced and unreflective rejection of her account, and to judge the account in her speech upon its merits. In short, to carefully consider 'new discourses' (i.e. non-traditional theories developed through investigation and reflection by Parmenides and other wise men), which though they challenge traditional accounts, may nevertheless prove themselves reliable and convincing, the result of a trustworthy method. This interpretation Fragment 7's conclusion does not change the general meaning of Parmenides' criticism against traditional knowledge. In fact, it would seem to support that argument, as I have outlined it. And Parmenides' criticism of traditional perspectives can be realized without the need to appeal to anachronistic appeals to "reason" as the differentiating and superior epistemic standard between mythic discourse and Parmenides' argumentation. 


\section{Conclusion}

This investigation set out to focus on the psychological aspects of Parmenides' poem, trying to make evident the author's insightful engagement in the observation of human mental behavior. In the process, a special meaning of verb vociv and its cognates was extracted from qualification Parmenides imputed upon its usage - 'to engage in cognitive operations'. This is an operation between 'thinking' and 'knowing' - the conceptions normally imputed

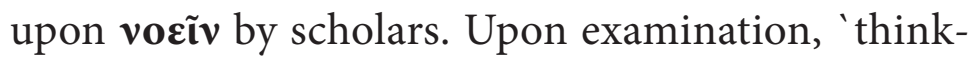
ing' turned out to be too inclusive a notion, applicable to all the aspects of knowing (a subject who knows, a cognitive mean, an object of knowing). On the other hand, 'knowing' was simultaneously too restrictive, referring to that kind of thinking directed to the specific knowing of an object. Instead, for Parmenides, the path of thinking is similar to capacities for hearing and seeing, requiring the employment of external tools in order to be free from prejudice, such that arguments can be analyzed with proper care, i.e. analyzing arguments with care). The chosen definition (cognitive operations), while quite techni$\mathrm{cal}$, proved quite functional in filtering out the ambiguities included in translations such as 'to think' and 'to know'. It also helped in resisting the temptation to go off-topic, enlarging the thesis of this discussion into epistemological and philosophical arenas, rather than strictly psychological.

Applying this understanding of vocĩv alongside an analysis of four selected fragments from Parmenides' poem, the following conclusions were drawn:

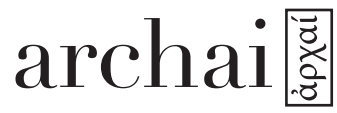

no 20, may-aug. 2017

Galgano, N. (2017). "Parmenides psychologist - Part Two: DK 6 and 7." p. 39-76 


\section{archai圈}

no 20, may-aug. 2017

Galgano, N. (2017). "Parmenides psychologist - Part Two: DK 6 and 7.” p. 39-76 a) Fragment 1: Using corporeal language, Parmenides distinguishes between states of certainty and doubt, and introduces the concept of persuasion as the intermediary activity between these conditions. Mind is that which can be in either state - it can be persuaded by true persuasion into certainty just as much as by the lack of true persuasion into doubt.

b) Fragment 2: Parmenides presents his reflections about how the mind works, positing two paths for thinking. As this inquiry is not focused upon following the philosophical upshots of this distinction, the main point of analyzing this fragment is to extract Parmenides' special usage of voeiv as picking out cognitive operations. This specialized technical meaning is used throughout the poem, and proves essential for understanding Parmenides' role as a psychological observer. Other psychological terminology in this passage is also analyzed, particularly the meaning of 'paths' as mental behavior, rather than physical 'pathways' to follow.

c) Fragment 6: Here it is argued that Parmenides is further examining the two paths of investigation he has identified in DK 2, distinguishing the ways in which they are followed by ordinary mortals given their natural psychology, in contrast to the manner of a wise man who has been sufficiently instructed by the goddess. There is a particular mental resource that mortals do not inherently possess, but which can be provided by the goddess. Without this resource, mortals believe that being and non-being are both the same and not the same, whereas the wise man with this resource can correctly discern that these are radically distinct. Thus, the wise man can follow the path 
of persuasion that accompanies the truth, whereas mortals whose mind behaves alike the deaf and the blind, forge inappropriate paths.

d) Fragment 7: Parmenides deepens the analysis identified in DK 6. Here, he begins by explicating his most famous precept - the absolute dissociation between being and non-being. This rather simple observation is not obvious - in fact, it tends to be missed entirely in common understanding. Parmenides then notes from his social observations that mortals tend to develop certain ways of thinking as a result of cultural habituation. This cultural habituation depends upon discourse which is seductive to the sense organs and senses (ears/hearing, eyes/sight, tongue). As these ways of thinking tend to unreflectively accept traditional views, and thus reject those which are contrary to traditional views out of prejudice, the wise man should not allow himself to be forced in this mental mode, but to judge the speech/argument on its merits. In summary, this fragment turns out to be a warning to those who would seek to think properly to avoid prejudices (derived largely from myth, and thus traditional religious thinking), in favor of more objective analysis.

Overall, this evidence demonstrates that Parmenides was an extraordinary observer human mental behavior, a fact which has extensive and profound implications for his philosophical thought. So much so that it seems impossible to adequately treat the implications in full here, and must await further discussion elsewhere. However, as I also do not think this work can be ever by adequately completed by myself

\section{archai嚎}

no 20, may-aug. 2017

Galgano, N. (2017). "Parmenides psychologist - Part Two: DK 6 and 7." p. 39-76 


\section{archai圈}

no 20, may-aug. 2017

Galgano, N. (2017). "Parmenides psychologist - Part Two: DK 6 and 7." p. 39-76 alone, I encourage others to take up and discuss Parmenides' psychological observations along with me.

\section{NotAS}

1 I would like to thank Jeremy Delong, a brave Parmenidean scholar who not only assisted in the translation of both parts of this article, but offered insightful commentary throughout, greatly improving my approach to this complex text. Of course, all problems in the present interpretation of Parmenides are my responsibility alone. To him, I extend only gratitude.

2 Simplicius is our only source for these lines, and there is a lacuna here in all the manuscripts.

3 Cordero, 2005, p. 145-164; 2007.

4 I use Cordero's translation here, whose seminal monograph borrows its title ("By Being, It Is") from this verse and posits a $\kappa \varepsilon \varepsilon$ to be the correct emendation for the lacuna at the end of 6.3."

5 Note the differences between this simple and literal translation and the translation of Cordero.

6 Capizzi (1975, p.37) translates "doppiezza", duplicity, here in the meaning of falsity, dissimulation.

7 An extensive review of scholarly views can be found in Zeller (1967, p.173- ${ }^{18} 3$, n. 3 de Giovanni Reale). The discussion has largely centered upon whether $\beta$ potoì was intended to pick out and criticize Heracliteans or not. The view that Heracliteans were the polemical target has been definitively laid to rest by Mansfeld (1960), who clearly showed that since the vocabulary used was already extant in lyric poetry, similar phrasing cannot be used as evidence for a Heraclitean target in Parmenides.

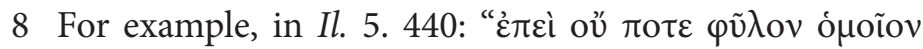

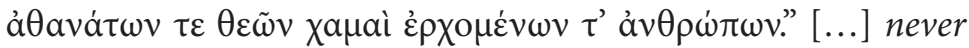
the same is the breed of gods; who are immortal, and men who walk groundling" (tr. Lattimore, 1951). A good synthesis of these notions are in the words of Mansfeld, quoted by Reale (1967, p.182): “... [these verses] are referred to a general Greek conception of the nature of human knowledge, which: 1) is nothing 
in comparison to divine knowledge; 2) in the way it is, does not suffice to the own life." Note that Parmenides uses both denominations: äv $\theta \rho \omega \pi$ o in DK B 1.27, 16. 2, 16.3, 19. 3 and Bpotoì in 1.30, 6. 4, 8. 39, 8. 51, 8. 61.

9 There is a case of synonymy between 8. 38-39, "ö $v o \mu(\alpha)$

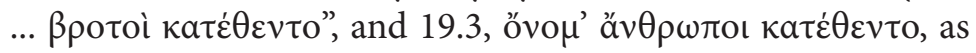
Cordero notices (1984, p.149, n.157). However, the fact that Parmenides uses them synonymously once does not mean that they are synonymous in all cases. Parmenides uses $\beta$ potoì four times $(1.30,6.4,8.39,8.61)$ and the adjective $\beta$ potcias once. These usages are always associated with the mind being astray

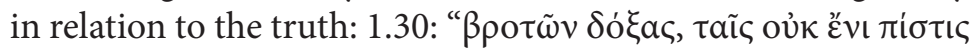

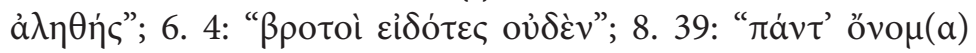

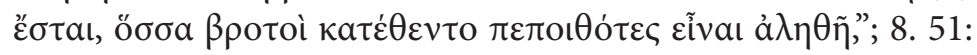

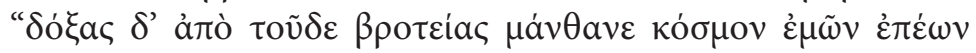

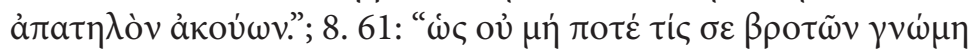
$\pi \alpha \rho \varepsilon \lambda \dot{\alpha} \sigma \sigma \eta$ ı." On the other hand, ä $v \theta \rho \omega \pi \mathrm{o}$ is used in several

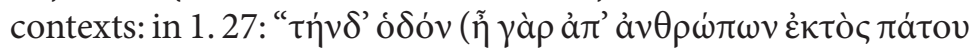

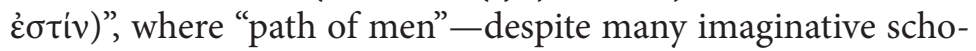
larly explanations-likely means simply 'the 'path' (i.e. road) of humans, rather than that of beasts or things (wind, water

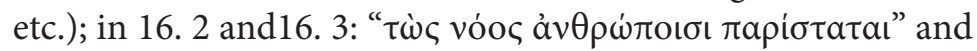

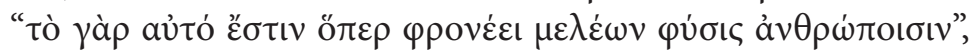
$a ̊ v \theta \rho \omega \pi$ o necessarily refers to humans in general (wise or not), since the context is anatomical-physiological descriptions; then, only in 19. 3, is it used as synonym of ßpotoi in the chuman condition" sense. Based upon the usage in the extant fragments,

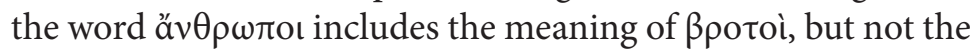
other way around.

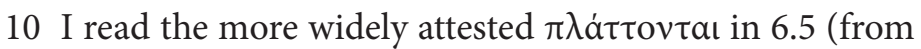
$\pi \lambda \dot{\alpha} \sigma \sigma \omega$. LSJ: mould, form an image of a thing in the mind, forge). This contrasts with the acceptance by most scholars of $\pi \lambda \dot{\alpha} \zeta o v \tau \alpha$ (from $\pi \lambda \dot{\alpha} \zeta \omega$. LSJ: baffle, go astray, wander. LSJ also includes the Parmenidean $\pi \lambda \dot{\alpha} \tau \tau o v \tau \alpha \iota$ in the entry $\pi \lambda \dot{\alpha} \zeta \omega)$, based upon Diels' adoption of the Aldine edition from 1526. This reading allows for a more coherent interpretation, whereby mortals "invent" a path through fantasizing (i.e. invent explanations), whereas $\pi \lambda \dot{\alpha} \zeta \omega$ would simply mean a "wandering of humans." A complete philological discussion can be found in Cordero (1984, p.147-8 and 2005, p.146-7). Those who

\section{archai}

no 20, may-aug. 2017

Galgano, N. (2017). "Parmenides psychologist - Part Two: DK 6 and 7." p. 39-76 


\section{archai圈}

no 20, may-aug. 2017 accept $\pi \lambda \dot{\alpha} \zeta \omega$ include: Diels, Barnes, Burnet, Coxon, Ruggiu, Tarán, Untersteiner, Verdenius, Zafiropulo. The few who accept $\pi \lambda \dot{\alpha} \tau \tau o v \tau \alpha \iota$ from $\pi \lambda \dot{\alpha} \sigma \sigma \omega$ are: Cordero, Cerri, O’Brien, Santoro e Ferrari.

11 As we will soon see below, this particularly problematic mental behavior arises in response to an initial problem - a certain lack of resources in the mind.

12 For example: Beaufret (1955, p.81), "l'absence de moyens"; Riezler-Gadamer (1970, p.29) "Hilflosigkeit"; Somville (1976, p.42) "limpuissance".

13 For example: Coxon (2009, p.58) "perplexity"; Casertano (1978, p.17) "incertezza"; Untersteiner (1979, p.135) "perplessità".

14 Once again, mind is described in its operations and, by the contextual qualification ( $\pi \lambda \alpha \kappa \tau$ òv, a verb of movement), it is easy to understand that Parmenides is focused on the operations themselves; however, the notion will remain ambiguous if we use the most common terms to translate (i.e. 'thought,' 'intellect,' etc.). For this reason, the translation here given to voñoal of 2.2 (and its cognates), cognitive operations, is essential to making clear the Parmenidean expression.

15 Most scholars, likely assuming a rhetorical-metaphorical meaning, translate following Diels, (1989, p.233) "zugleich", "for example: at once" (Palmer, 2009, p.114); "ad un tempo" (Reale, 1991, p.95); "tão surdos como cegos" (Santoro, 2011, p.91); "at the same time" (Tarán, 1965, p.54). Some alternative approaches include: "ciegos y sordos" (Cordero, 2005, p.219, who simply does not translate $\delta \mu \tilde{\omega} \varsigma$ ); "deaf and blind alike in bewilderment" (Coxon, p.58, who, linking ó $\mu \tilde{\omega} \varsigma$ to $\tau \varepsilon \theta \eta \pi$ ó $\tau \varepsilon \varsigma$, understands the meaning to be 'alike they were in bewilderment'). Others translate more correctly, I think, 'alike': "deaf alike and blind" (Barnes, 1982, p.124), "deaf and blind alike" (Long, 1975, p.85) e "como surdos e cegos" (Cavalcante de Souza, 1978, p.142).

16 It is worth noting that even amongst those who translate ó $\mu \tilde{\omega} \varsigma$ as 'alike', many take metaphorical meaning-which "deaf and blind" must be here-in the wrong direction. They think that 'deaf and blind' would define an epistemological metaphor of some kind, a comparison to a general theory of human 
knowledge dependent upon empirical observations rather than reason. For example, consider Long (1975, p.87): "Now the deafness and blindness might be a part of the rhetorical description

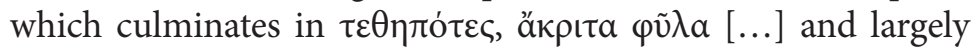
metaphorical. Or it may, if only indirectly, be connected with the condemnation of sense perception in B 7.3-5." Nevertheless, there is no such metaphor here. As Parmenides is simply attempting to describe a failure in mortal mental behavior, there is no condemnation of sense perception; he is not talking about senses, but about "paths of thought" (cognitive operations).

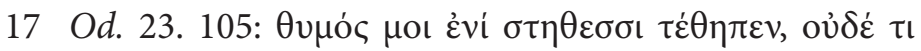

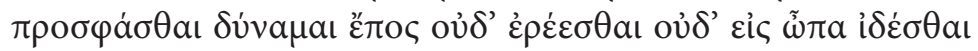
ह่vavtíov.

18 "Much-discussed" because many scholars like to discuss 'the paths' in Parmenides, particularly their quantity and characteristics. However, if we substitute less suggestive and more prosaic terminology for $\kappa \dot{\varepsilon} \lambda \varepsilon v \theta 0 \varsigma$, such as 'process' or 'procedure', perhaps such extensive discussion would not ensue. The

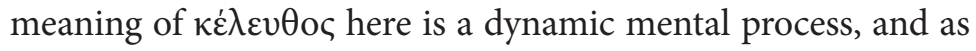
such, a natural (human) phenomenon, and not a literal path to follow or not.

19 An example, the LSJ reports this meaning (i.e. palin épécl, 'speak against') to already be present in Homer. In the Iliad ( 9 . 56), after the speech of Diomedes, Nestor says: "Not one man of all the Achaians will belittle your words nor speak against

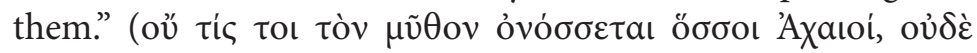

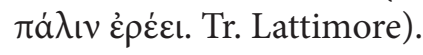

20 The proper reconstruction and arrangement of the fragments, gathered from quotations by doxographers and commentators, is a distinct puzzle for the Parmenidean scholar. I have relied primarily on Diels-Kranz's arrangement, as do most scholars, though many other editors suggest other arrangements. In the case of fragment 7 in particular, it is a collage of Diels-Kranz's making, adopted only for didactical convenience here.

21 As examples, I report here just two the editors: Coxon (2009, p.308): "Parmenides repeats the warning given in fr. 5 (DK B 6) against believing in the reality of sensible objects"; Tarán (1965, p.78): "What Parmenides says in this passage (vv. 3-5) is that senses are responsible for the acceptance of the way of non-Being.".

\section{archai蒡}

no 20, may-aug. 2017

Galgano, N. (2017). "Parmenides psychologist - Part Two: DK 6 and 7." p. 39-76 


\section{archai圈}

no 20, may-aug. 2017

Galgano, N. (2017). "Parmenides psychologist - Part Two: DK 6 and 7." p. 39-76
22 For example, Untersteiner (1979, p.CXXX): "Infatti, pro-

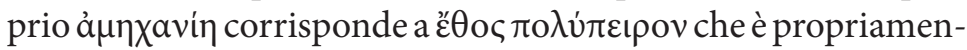
te la causa dell' ả $\mu \eta \chi \alpha v i n$ poiché corrisponde all'atteggiamento della meschinità determinate dall'abitudine".

23 Calogero incorrectly translates "abitudine allesperienza del molteplice" (1977, p.38). Verdenius translates correctly ("custom that comes of much experience"), but misunderstands it as an expression of a perception of inconstancy: "The method underlying this third way has the same character of inconstancy." (1964, p.55).

24 A similar criticism is presented by Heraclitus in fragment DK 21 B 40: "Much learning does not teach understanding. For it would have taught Hesiod and Pythagoras, and also Xeno-

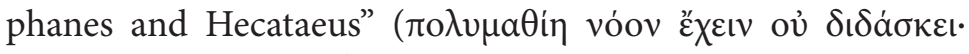

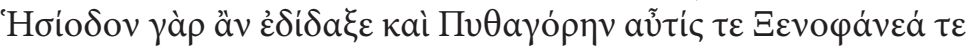
кaì'Eкaтaĩov) (tr. Kahn, 1979, p.37). However, Heraclitus' criticism is not against a particular way of thinking. This is evident here, as it associates both traditional and non-traditional poets (Hesiod and Xenophanes), alongside the very different personages of Pythagoras (a researcher and mystic) and Hecataeus (a researcher of pragmatic culture, and possible geographer). In doing so, Heraclitus is actually criticizing polymathia, whether traditional or not. When Heraclitus does criticize tradition, he does it in his own specific way, generically censuring cultural behaviors, rather than the behavior of a specific person (Fragments DK 21B 5, 14, and 15). This fact further testifies for Parmenides' own cultural criticism in this passage, as he is similarly criticizing cultural behavior at a more general (i.e. non-personal) level, by criticizing mental behavior of mortals in general. Thus, Parmenides can be seen as sharing the tendency of other Presocratics (Heraclitus, Xenophanes, etc.) to criticize mythic thought in favor of new models.

25 Scholars from the second half of the past century on have largely set aside the interpretation of a Parmenidean warning against senses, and embraced the idea that Parmenides is warning only against the bad use of senses here. This move requires going against an entry in the LSJ itself, which suggests a particular contextual translation of vón $\mu \alpha$ as: "in Philos., thought, concept, opp. sensation, sense-presentation, Parm. 8.34 etc.;”. Accepting this philosophical definition for vón $\mu$ a as 'thought in 
opposition to sensation', the suggestion of an opposition between vón $\mu \alpha$ in 7.2 and the role of senses described in 7.3-5 is quite strong. Nevertheless, this interpretation should be resisted.

26 Almost all scholars translate "judge by reason" or the equivalent "by argument". The exception is due to some very few authors who consider Parmenides a shamanic figure, hence, for them, reason is not a measure for truth. Notwithstanding, even Kingsley, who defends exactly this interpretation of Parmenides, though translating 'by speech', does not escape from understanding it in the common manner. Instead, he argues that the Greek is corrupted, suggesting some $a d$ hoc and incorrect alterations (i.e. $\lambda$ ó $\gamma o v$, genitive, for $\lambda$ ó $\gamma \omega \mathrm{l}$, dative), in order to achieve this result: "but judge in favor of the highly contentious demonstration of the truth contained in the words as spoken by me." (Kingsley, 2003, p.136-140).

27 This word is the object of many variant interpretations. While it is not necessary to examine this in-depth in this inquiry, as it is restricted to the search for psychological vocabulary, it is worth noting that the original Homeric meaning (reproach, disgrace, dishonor, LSJ) seems to have already been altered by the time of Parmenides. The same LSJ offers this Parmenidean passage as an explicit example of the meaning "argument of disproof or refutation". Notwithstanding, this is the meaning used by Plato in reference to Socrates' method, many decades after. In the literature contemporary to Parmenides, with seldom exceptions, the main meaning is 'test' or 'proof'. See the Lesher (1984) and against Furley (1989).

28 On eunomy of Elea and nomothetia of Parmenides, see Mele, 2005, and Mele, 2006.

\section{BibliografiA}

AUBENQUE, P. (1987). Syntaxe et sémantique de lêtre. In AUBENQUE, P. (dir.). Études sur Parménide, tomo II, Paris, Ed. Vrin, p.102-134.

BARNES, J. (1982). The Presocratic philosophers. $2^{\text {a }}$ ed. revisada, reimpressão 2000, Londres, Routledge.

\section{archai蒡}

no 20 , may-aug. 2017

Galgano, N. (2017) "Parmenides psychologist - Part Two: DK 6 and 7." p. 39-76 


\section{archai圈}

no 20, may-aug. 2017

Galgano, N. (2017). "Parmenides psychologist - Part Two: DK 6 and 7." p. 39-76
BEAUFRET, J. (1955). Le poème de Parménide. Paris, Presses universitaires de France.

BURNET, J. (1920). Early Greek philosophy. 3a ed. Londres, A \& C Black.

CALOGERO, G. (1977). Studi sulleleatismo. $2^{\mathrm{a}}$ ed. Florença, La Nuova Italia.

CAPIZZI, A. (1975). Introduzione a Parmenide. Bari, Laterza.

CASERTANO, G. (1978). Parmenide il metodo la scienza l'esperienza. Nápoles, Guida Editori.

CAVALCANTE DE SOUZA, J. (dir.) (1978). Os pré-socráticos. S. Paulo, Abril Cultural.

CERRI, G. (1999). Parmenide di Elea - Poema sulla natura. Milão, BUR.

CORDERO, N.-L. (1984). Les deux chemins deParménide. Édition critique, traduction, études et bibliographie. Paris, Vrin e Bruxelles, Ousia.

CORDERO, N.-L. (2005). Siendo, se és. Buenos Aires, Editorial Biblos.

CORDERO, N.-L. (2007). En Parménides, 'tertium non datur'. Anais de Filosofia Clássica, 1, n 1, p. 1-13. Rio de Janeiro.

COXON, A. H. (2009). The fragments of Parmenides - Revised and expanded edition. Las Vegas, Parmenides Publishing. 
CURD, P. (1991). Parmenidean Monism. Phronesis, $36, \mathrm{n}^{\circ} 3, \mathrm{p} .241-264$.

https://doi.org/10.1163/156852891321052688

DIELS, H.; KRANZ, W. (1989). Die Fragmente der Vorsokratiker. Reimpressão da $6^{\text {a }}$ ed. de 1951, Zurich, Weidmann.

FERRARI, F. (2010). Il migliore dei mondi impossibili. Roma, Aracne Editrice.

FINKELBERG, A. (1990). Studies in Xenophanes. Harvard studies in classical philology, 93, p.103-167.

https://doi.org/10.2307/311284

FREEMAN, K. (1948). Ancilla to the Pre-Socratic Philosophers. Harvard University Press.

FURLEY, D. (1989). Truth as what survives the elenchos: an idea in Parmenides. In HUBY, P.; NEAL, G. (eds.). The criterion of truth. Essays written in honour of George Kerferd. Liverpool, Liverpool University Press.

KAHN, C. H. (1979). The art and thought of Heraclitus. Cambridge University Press, Cambridge.

KURFESS, C. J. (2012). Restoring Parmenides' poem: essays toward a new arrangement of the fragments based on a reassessment of the original sources. Tese de doutorado, University of Pittsburg, Pittsburg.

LATTIMORE, R. (1951). Iliad - translation. University of Chicago Press, Chicago.

\section{archai圈}

no 20 , may-aug. 2017

Galgano, N. (2017). "Parmenides psychologist - Part Two: DK 6 and 7." p. 39-76 


\section{archai圈}

no 20, may-aug. 2017

Galgano, N. (2017). "Parmenides psychologist - Part Two: DK 6 and 7." p. 39-76
LESHER, J. H. (1984). Parmenides' Critique of Thinking. The polydêris elenchos of Fragment 7. In Oxford studies in ancient philosophy 2, Oxford, OUP, 1-30.

LESHER, J. H. (2001). Xenophanes of Colophon: fragments. Toronto, University of Toronto Press.

LIDDELL, H. G.; SCOTT, R.; JONES, H. S.; McKENZIE, R. (1996). A Greek-English Lexicon. Rev. and augm. throughout. Oxford, New York, Clarendon Press, Oxford University Press.

LONG, A. A. (1975). The principles of Parmenides' cosmogony. In ALLEN, R. E.; FURLEY, D. J. (eds.). Studies in Presocratic Philosophy, vol II, p.82-101, Atlantic Highlands, Humanities Press.

MANSFELD, J. (1960). Die Offenbarung des Parmenides und die menschliche Welt. Assen.

MELE, A. (2005). Gli eleati tra oligarchia e democrazia. In AAVV Da Elea a Samo, filosofi e politici di fronte all'impero ateniese. Atti del convegno di studi. Nápoles, Arte Tipografica editrice.

MELE, A. (2006). L'identità di Elea: da Platone a Strabone. In AAVV Velia, Atti del quarantacinquesimo convegno di studi sulla Magna Grecia. Nápoles, Arte Tipografica Editrice.

MURRAY, A. T. (1919). Odyssey - translation. Revised by DIMOCK, G., reset 2004, Loeb Classical Library, Cambridge.

NUNES, C. A. (2001). Ilíada - tradução. Rio de janeiro, Ediouro. 
PALMER, J. (2009). Parmenides and the presocratic phylosophy. Oxford, OUP.

https://doi.org/10.1093/acprof:oso/9780199567904. 001.0001

REALE, G. (1967). Atualizações e notas a Zeller, E. (1967), La filosofia de Greci nel suo svluppo storico. Parte I, I presocratici. Volume III. Eleati.

REALE, G. (1991). I frammenti del poema di Parmenide "Sulla natura" - traduzione e note. In REALE, G.; RUGGIU, L. (1991).

REALE, G.; RUGGIU, L. (1991). Parmenide, Poema sulla natura. Milão, Rusconi.

RIETZLER, K.; GADAMER, H. G. (1970) Parmenides. Frankfurt am Main, Vittorio Klostermann.

RUGGIU, L. (1975). Parmenide. Veneza, Marsilio Editori.

SANTORO, F. (2011). Filósofos épicos I - Parmênides e Xenófanes. Rio de Janeiro, Fundação Biblioteca Nacional, Hexis.

SOMVILLE, P. (1976). Parménide d'Élée, son temps et le nôtre. Paris, Vrin.

TARÁN, L. (1965). Parmenides. A text with translation, comentary and critical essay. Princeton, Princeton University Press.

UNTERSTEINER, M. (1979). Parmenide, testimonianze e frammenti. Florença, La Nuova Italia.

\section{archai蒡}

no 20, may-aug. 2017

Galgano, N. (2017). "Parmenides psychologist - Part Two: DK 6 and 7." p. 39-76 


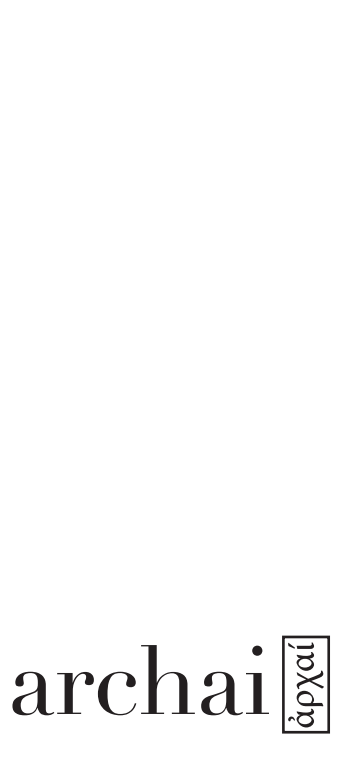

VERDENIUS, W. J. (1964) Parmenides, some comments on his poem. Reimpressão de 1942, Amsterdam, Hakkert.

ZELLER, E. (1967). La filosofia de Greci nel suo sviluppo storico. Parte I, I presocratici. Volume III. Eleati. 5a ed. Tradução italiana de MONDOLFO, R.; atualização de REALE, G., Florença, La Nuova Italia.

Submitted in October 2015 and accepted for publication in January, 2016.

no 20, may-aug. 2017

Galgano, N. (2017).

"Parmenides psychologist - Part Two: DK 6 and 7." p. 39-76 